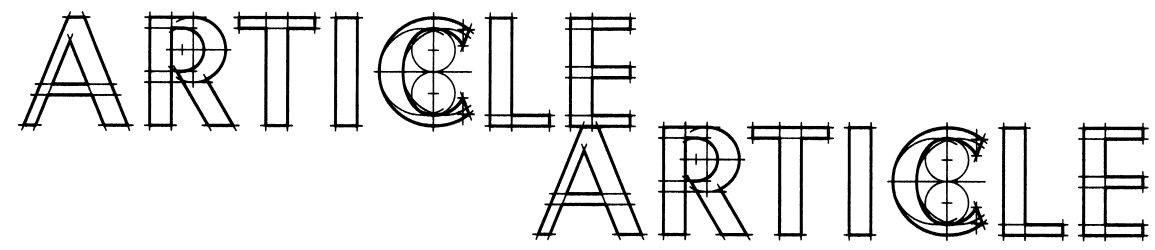

\title{
Bioart: Biotechnology and Art
}

\section{Bioart: Biotechnologie et art}

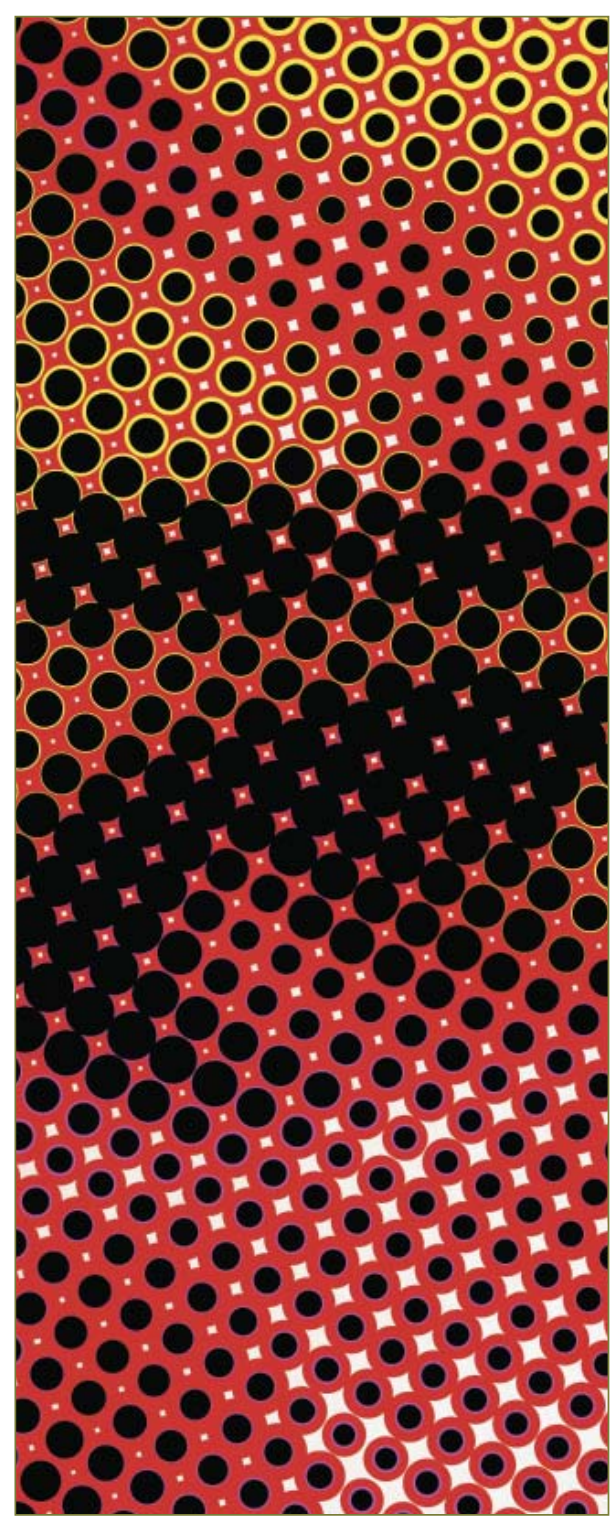

Art has been historically associated with cultural and technological changes in society.

Recently imaging, genetics and new biological sciences have been utilized in what is known as Bioart.

Visual science digital imaging, photonics, genomics, tissue engineering, and cloning utilize colored pixels.

The visual scientist, biologist, geneticist, eyecare practitioner and artist work with a variety of bio-technology images. These images may be considered as an inspiration for Bioart.

Internet references to some ophthalmic digital technology sites are provided. The Optometrist may view digital ocular diagnostic and therapentic images with an appreciation of its aesthetics.

L'art a de tout temps été associé aux changements technologiques et culturels d'une société.

Récemment, on a utilisé l'imagerie, la génétique et les nouvelles sciences biologiques dans ce qu'on appelle le bioart.

L'imagerie numérique, la photonique, la génomique, l'ingénierie cellulaire et le clonage utilisent des pixels colorés.

Le scientifique, le biologiste, le généticien, le praticien des soins de la vue et l'artiste visuels travaillent avec une diversité d'images biotechnologiques qui peuvent être considérées comme une inspiration pour le bioart.

On fournit des liens vers des sites Internet de technologie numérique ophtalmique. L'optométriste a la possibilité de voir des images numériques de diagnostic et de thérapie oculaires dont il peut apprécier le caractère esthétique.
Howard Backman $\mathrm{LSCO}, \mathrm{OD}, \mathrm{FAAO}$ 755 boul. St. Jean Suite 130

Pointe-Claire,QC H9R $5 \mathrm{M} 9$

Tel: 514.630 .7400 Fax:514.630.9668 E-mail: h_backman@ alcor.concordia.ca

Keywords: Bioart, biotechnology, genomics, bio-photonics, imaging, art, culture.

Mots clés: Bioart, biotechnologie,

génomique, biophotonique, imagerie, art, culture. 


\section{INTRODUCTION}

Bioart is an art practice in which the medium is living matter and the "works of art" are produced in laboratories and/or artist's and designers studios. The tool is biotechnology, which includes such technologies as genetic engineering and cloning. The materials used by Bioartists are cells, DNA molecules and living tissue. ${ }^{1}$

Bioart comprises:

(1) Cloning Technologies

2) Transgenics (Genetic Engineering)

(3) Tissue Engineering

(4) Human Genome Project/Reproductive Technologies

Bioart may utilize diagnostic and therapeutic imaging in medicine and Optometry. References to ophthalmic internet web sites are provided for the artistic appreciation of ocular imaging.

\section{BIOART AND GENOMICS}

Historically art depicting living animals has been known since the prehistoric times. Leonardo Da Vinci is an example of a bioartist. He was a scientist, technologist and artist who combined art and biotechnology in his human anatomical sketches. ${ }^{2}$

More recently, Frank Netter, MD (1906-1991) produced numerous medical illustrations in his books and Clinical Symposia. ${ }^{3}$ Today, ocular imaging has replaced some anatomic and physiological artistic illustrations.

One recent source of biological information is genomics, the study of an organism's entire genome. It determines the entire DNA sequence of organisms and fine-scales genetic mapping. Study of the full set of proteins in a cell type or tissue and the changes during various conditions, is called proteomics. Genomics was developed in the 1990 's with genome projects. ${ }^{4}$ Proteomics and genomics are used as a source inspiration for Bioart.

The first genetically hybrid life forms exhibited in art were Edward Steichen's "Delphiniums" in 1936. This introduced genetics into the art world.

Eduardo Kac is a transgenic artist.${ }^{5}$ One of his works, titled "Genesis", could permit viewers to activate genes derived from bacteria under ultraviolet (UV $488 \mathrm{~nm}$ ) light causing genetic mutations. He obtained some genes from a laboratory, implanted them into a bacteria which then grew in a petri dish under UV light.

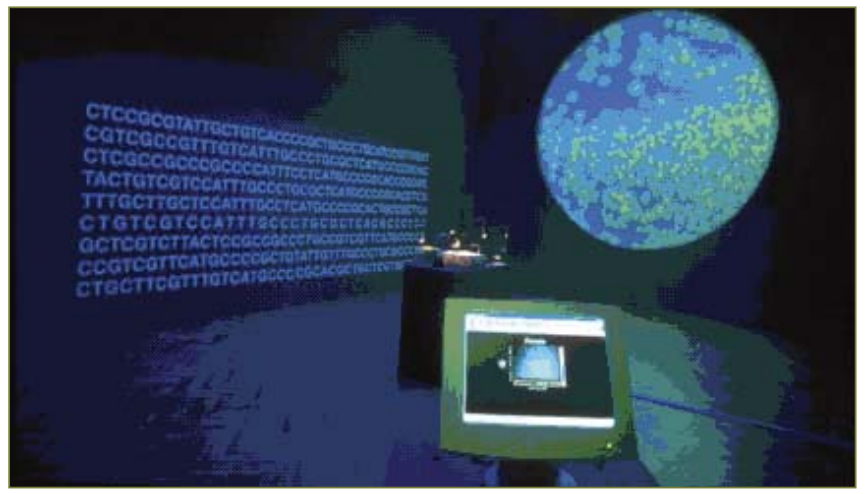

Figure 1. GENESIS. Eduardo Kac ${ }^{5}$

"Genesis is a transgenic artwork that explores the intricate relationship between biology, belief systems, information technology, dialogical interaction, ethics, and the Internet. The key element of the work is an "artist's gene", a synthetic gene that was created by Kac by translating a sentence from the biblical book of Genesis into Morse Code, and converting the Morse Code into DNA base pairs according to a conversion principle specially developed by the artist for this work. The sentence reads: "Let man have dominion over the fish of the sea, and over the fowl of the air, and over every living thing that moves upon the earth." It was chosen for what it implies about the dubious notion--divinely sanctioned-of humanity's supremacy over nature. Morse code was chosen because, as the first example of the use of radiotelegraphy, it represents the dawn of the information age--the genesis of global communication. The Genesis gene was incorporated into bacteria, which were shown in the gallery. Participants on the Web could turn on an ultraviolet light in the gallery, causing real, biological mutations in the bacteria. This changed the biblical sentence in the bacteria. After the show, the DNA of the bacteria was translated back into Morse code, and then back into English. The mutation that took place in the DNA had changed the original sentence from the Bible.

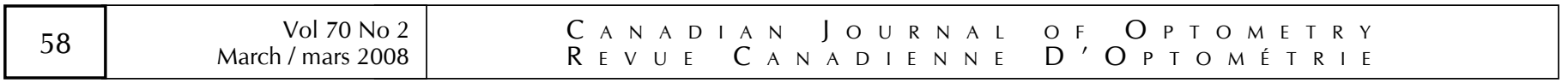




\section{ARTICLE ARTICLE}

The mutated sentence was posted on the Genesis web site. In the context of the work, the ability to change the sentence is a symbolic gesture: it means that we do not accept its meaning in the form we inherited it, and that new meanings emerge as we seek to change it." (5)

Alba, another work by Eduardo Kac "created a green fluorescent rabbit created with an enhanced version (i.e. synthetic mutation) of the original wild-type green fluorescent gene found in the jellyfish Aequorea Victoria." ${ }^{5}$ The rabbit glows green under a specific ultraviolet light (maximum 488nm).

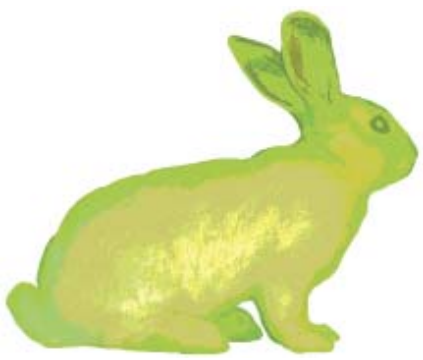

Figure 2. ALBA. Eduardo $\mathrm{Kac}^{5}$

\section{ARTIFICIAL LIFE}

Another use of biology in art is the use of artificial-life art software imitating some aspect of biology. It was developed in the early 1990's. Artficial genetics and mutations allowed the viewer to interact with stereoscopic creatures and ecosystems. Life spacies is an artificial life environment applying genetics, mutation, breeding and evolution to artworks. Life spacies can translate written text into a genetic code of a virtual creature. Form, shape, colour, texture and the number of body limbs can be created through interaction with the program. Christa Sommerer and Laurent Mignonneau's Life Species II Modeling Complexity for Interactive Art is an example of this art form. ${ }^{6}$

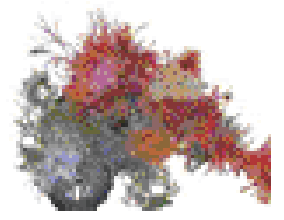

Figure 3. Life Spacies. 1997. Sommerer Mignonneau6

\section{OTHER FORMS OF BIOART}

Joe Davis at the department of Biology at MIT uses Molecular Biology and bioinformatics in his Bioart. ${ }^{8} \mathrm{Us}-$ ing genetic engineering he inserted some encoded DNA into E. coli bacterium. This pioneering work was influenced by Eduardo Kac's Genesis.

Some artists such as Natalie Jeremijenko used Cloning to create life as artwork. She demonstrated cultural and environmental differences in 100 cloned trees.

Gunther von Hagens has developed preserved human body sculptures using Plastination to teach lay people about anatomy of the human body, its functions, diseases and physical changes. ${ }^{7}$

\section{IMAGING}

Biophotonics deals with the interaction of organic materials with light and other forms of radiant energy. Computer technology, video and imaging using optics, lasers, imaging, fibre-optics, electro-optics and photonics make up the term Photonics. This includes the emission, detection, absorption, deflection, selection, modification and creation of radiation by and from all living organisms and organic materials. Biophotonics has many applications in the fields of medicine, genetics, biology, agriculture and environmental science. ${ }^{8}$

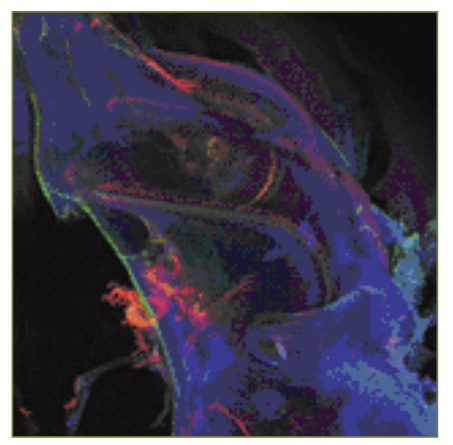

Figure 4. Biophotonics. Cochlea ${ }^{9}$

The Bioartist can draw upon many ocular imaging sources as an inspiration for Bioart. Imaging using colour coded pixel, 3-D imaging, etc. produces topographic images of the surface of the eye, the anterior and posterior segments. ${ }^{9}$ 


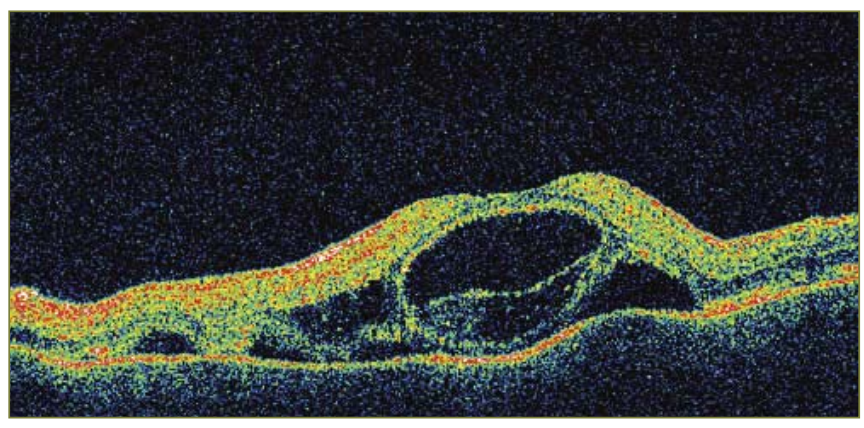

Figure 5. Age Related Macular Degeneration. Stratus OCT. Zeiss Meditec. ${ }^{16}$

Imaging such a tear ferning, thermography, fluorescence, live-cell imaging, corneal topography, ultrasonic biomicroscopy, ultrasound, Scheimpflug lens imaging, optical coherence tomography (OCT), 3-D Confocal microscopy, retinal nerve fibre analysis, endoscopy, brain imaging (MRI,PET,CT scans, etc.), biomarkers, holography, and doppler retinal blood flow may be sources of Bioart.

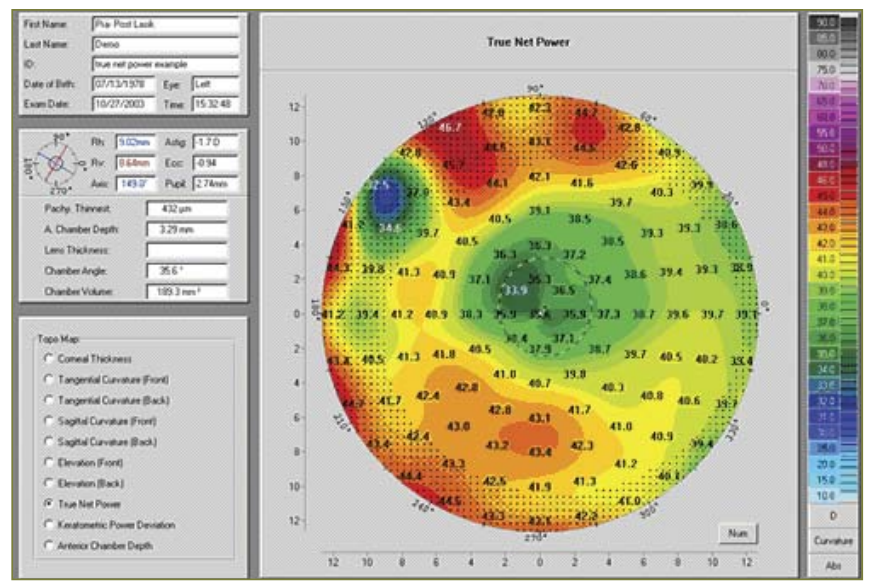

Figure 6. Corneal Topography. Oculus Pentacam ${ }^{20}$

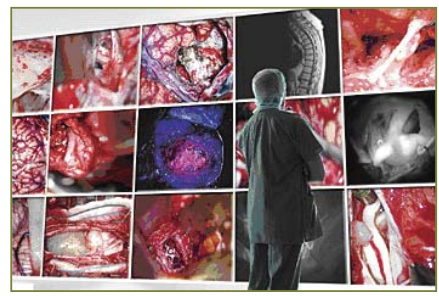

Figure 7. Intraocular Imaging. Dicon Module. Zeiss Meditec ${ }^{16}$

\section{OPHTHALMIC SOURCES OF BIOART}

The National Eye Disease Genotyping Network (eyeGENE -NEI)) and the National Human Genome Re- search Institute (NIH) also provides information and images which may be used by the Bioartist. ${ }^{9,10}$ More than 30,000 genes involved in the function of the human body have been found in a single human cell. The information obtained from genetic (DNA) analysis has the potential to revolutionize the diagnosis, prevention and treatment of human diseases. Genetic analysis is also used for identifying drug-resistant strains and tailoring individual treatments.

The Bioartist uses a multitude of vision perception techniques involving form, colour, stereopsis, contrast sensitivity, figure-ground., peripheral versus central vision, motion, etc. Many studies of visual perception published in the Journal of Vision may explain the basis of visual effects utilized in Bioart. ${ }^{11}$

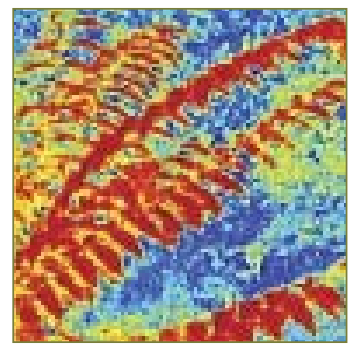

Figure 8. Hansen and Hess, Journal of Vision ${ }^{11}$

\section{CONCLUSION}

Bioartists all have a tendency towards:

(1) Reminding people about the ever-present complexities of vitality, mortality and mutation all around us.

2) Giving non-experts the ability to speak intelligently about science without having to be a scientist.

3 Providing hands-on labs or exhibitions designed to get rid of fears of complexity while maximizing debates on intelligent applications of technology.

(4) Exhibiting works which rework preconceptions about relationships among human culture, other living beings and the environment. ${ }^{12,13}$

Bioart utilizes human, animal and virtual reality images and biotechnology techniques on the internet or in museums to create life-like artworks linking biology and art. Genetic art seeks "to break down the psychic and physical barriers between art and living reality". The artists

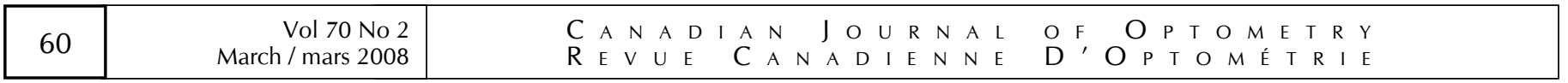




\section{ARTICLE ARTICLE}

use the control of biology for the good of humanity. Bioart relocates humanity within the complex ecological systems of life. ${ }^{13}$

\section{ACKNOWLEDGEMENTS}

The author would like to acknowledge the assistance of Professor Ernestine Daubner, Fine Arts department, Concordia University, Montreal, Qc.

\section{BIOART INTERNET SITE REFERENCES}

1. Wikipedia.org

2. Da Vinci's Short Biography.- http://sulcus.berkeley. edu?FLM/SH/MDL/Inventor/DaVinci.Bio.html

3. The BioArt of Frank Netter.MD usip.edu/museum/ netter.shtml

4. Amy M. Youngs.The Fine Art of Creating Life. http:/ / accad.osu?edu/ ayoungs/ fineart.html

5. eKac.org and Daniel Langlois foundationfondation-langlois.org

6. exxe.pt/bioart/sommerer.html

7. viewingspace.com/genetics_culture/pages_genetics_ culture/gc_w03/davis_joe.htm

8. bodyworlds.com

9. Biophotonics.com

10. nei.nih.gov/resources/eyegene/tableforgenes.asp and genome.gov/10001691

11. Journal of Vision.org. Hansen, B.C. \& Hess, R. F, discrimination of Amplitude Spectrum Slope in the Fovea \& Parafovea \& the Local Amplitude Distributions of Natural Scene Imagery. J. of Vision. vol6,No.7,Article 3,pp696-711

12. www.ekac.org/daubner.html

13.Adam Zaretsky. fondation-langlois.org

\section{SOME OCULAR IMAGING SITES:}

14. eyephoto.ophth.wisc.edu/ResearchAreas/oct/oct7. htm

15. biotogen.com

16 meditec.zeiss.com

17. heidelberengineering.com

18. optovue.com

19. topconcommercial.com

20. roi2020.com/Images/Products/Oculus/Pentacam Brochure.pdf
On January 1, 2008,

THOMAS F. FREDDO, O.D., PH.D., F.A.A.O

assumed the Presidency of the International Society

for Eye Research www.

ISER.org. He was elected

in 2006 and has served

the past two years as

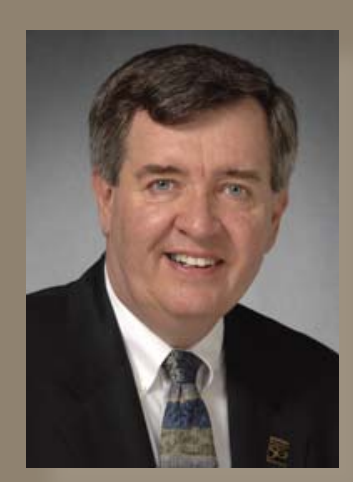

President-Elect. He is the first optometrist to lead

this international organization. ISER was founded

in 1968 under the leadership of Dr. Endre Balazs

who developed the first clinical viscoelastic -

Healon. The mission of the International Society

for Eye Research is to support, sustain and

propagate excellent eye research throughout the

world. This is achieved by enhancing international

communication and collaboration, by providing a

forum for dissemination of information among eye

researchers and by developing and sustaining the

skills and resources of the eye research community.

ISER holds a biennial meeting. Its next meeting

will be held in Beijing, China, September 24-29,

2008. The 2010 meeting will be held in Montreal,

July 18-23, 2010. ISER also sponsors the highly-

regarded journal Experimental Eye Research and Dr.

Freddo currently serves as an Executive Editor for

this journal.

Dr. Freddo currently serves as Professor and Director of the School of Optometry at the University of

Waterloo in Ontario. Prior to 2006, he had served

as Professor and Vice-Chairman for Research in the Department of Ophthalmology at Boston University School of Medicine. Dr. Freddo has served on the Board of Directors of the American Academy of Optometry and on the Long-Range Planning Committee for the Association for Research in Vision and Ophthalmology. He is a former Ezell Fellow and a recipient of the Glenn A. Fry Award from the American Optometric Foundation. 